\title{
Literarni liki v kratkih zgodbah Andreja Blatnika
}

\author{
Darja Pavlič
}

Filozofska fakulteta UL, Oddelek za slovenistiko, Aškerčeva 2, 1000 Ljubljana, Slovenija https://orcid.org/0000-0003-2605-9556

darja.pavlic@ff.uni-lj.si

\begin{abstract}
Kratke zgodbe Andreja Blatnika ne temeljijo na dejanjih literarnih likov, pač pa $v$ ospredje postavljajo njihovo zavest. Primerno orodje za njihovo analizo so zato koncepti, razvitiv okviru kognitivne naratologije. V članku posebej izpostavim pojem izkustvenost (experientiality), ki ga je za razlago pripovednosti uvedla Monika Fludernik. Ker gre za kompleksen pojem, ga skušam razložiti tako, da opozorim na njegovo povezanost z bralci, literarnimi liki in pripovedovalci. Na ravni literarnih likov je izkustvenost mogoče enačiti z njihovo zavestjo, še posebej če to razumemo v povezavi s telesom oz. kot utelešeni um. Blatnikovi literarni liki se čustveno in fizično odzivajo na dogodke, razmišljajo o svojih nikoli uresničenih načrtih, pogosto tudi o tem, kako jih vidijo drugi. Pri branju umov drugih likov praviloma niso uspešni, kar pokažem z analizo treh izbranih kratkih zgodb: postmodernistične "Zgodbe o Rošlinu in Verjanku", minimalistične kratke zgodbe »Vlažne stene in modernistične kratke zgodbe "Iz strasti«.
\end{abstract}

Ključne besede: kognitivna naratologija / Fludernik, Monika / slovenska književnost / kratka zgodba / Blatnik, Andrej / literarni liki / pripovedna struktura / izkustvenost / zavest

\section{Literarni liki med dejanji in zavestjo}

Literarni liki so $\mathrm{v}$ tradicionalnih poetikah in klasičnih naratoloških študijah pogosto obravnavani v odnosu do dejanj. ${ }^{1}$ Trditev je mogoče podkrepiti z ugotovitvijo, da so bila za Aristotela dejanja, ki jih liki izvajajo, bolj pomembna kot študij njihovih značajev, Vladimir Propp in Algirdas Julien Greimas pa sta jih analizirala kot nosilce funkcij oz. aktantskih vlog. V skladu s tradicijo, ki daje prednost dejanjem pred liki, je Gerald Prince (A Dictionary 12) poudaril njihovo vpletenost $\mathrm{v}$ antropomorfna dejanja in jih strnjeno definiral kot "akterje $\mathrm{z}$ antropomorfnimi lastnostmi ${ }^{2}{ }^{2}$ Poststrukturalizem je obravnavo likov pomaknil v območje semiotike,

\footnotetext{
${ }^{1}$ Članek je nastal v okviru raziskovalnega programa P6-0024, ki ga je financirala Javna agencija za raziskovalno dejavnost Republike Slovenije.

${ }^{2} \mathrm{Ta}$ in preostali prevodi iz tujejezičnih virov so delo Darje Pavlič.
} 
pri čemer je lik obravnavan kot "tematski element, semantični kompleks, makroznak, ki je sestavljen iz semov in poenoten z lastnim imenom (kot je opisano v delu $S / Z$ Rolanda Barthesa) «(Palmer, Fictional 37). Prav v omenjeni Barthesovi študiji je Shlomith Rimmon-Kennan prepoznala poskus preobrniti tradicionalno hierarhijo med dejanjem in likom, saj Barthes nakazuje možnost, da je lik za pripoved pomembnejši od dejanja (Rimmon-Kennan 35). Poleg različne obravnave razmerja med dejanjem in likom je treba omeniti lastnost, ki povezuje strukturalistični in poststrukturalistični pristop: oba sta nemimetična in zato likov ne enačita $\mathrm{z}$ ljudmi.

$\mathrm{Z}$ razvojem postklasične naratologije in upoštevanjem teorije možnih svetov se je v razprave o literarnih likih vrnilo prepričanje, da jih je smiselno obravnavati kot fiktivne ljudi. ${ }^{3}$ Prelomno vlogo pri uvajanju danes splošno sprejetega pogleda, da so literarni liki »elementi konstruiranega pripovednega sveta", je v 80. in 90. letih 20. stoletja odigral Uri Margolin (Jannidis 11). Margolin je v svojih študijah obravnaval različne definicije literarnih likov. Kot je ugotovil Alan Palmer, nobenemu konceptu ni pripisal absolutne veljave, prednost pa je dal obravnavi literarnih likov kot nedejanskih posameznikov, ki obstajajo v možnem svetu in jim je mogoče pripisati fizične, socialne in mentalne lastnosti. K slednjim je prišteval dogodke (kognitivni dogodki, emocionalni dogodki, odločanje, zaznavanje) in notranja stanja (kot so nabori vednosti in prepričanj, naravnanosti, želje, cilji, načrti, razpoloženja). Margolin je ugotovil, da je v primerjavi s pristopi, ki se ukvarjajo z govornimi položaji ali aktantskimi vlogami, teorijo možnih svetov mogoče aplicirati tudi na ontološko problematične besedilne svetove in z njo obravnavati tako "realistično" (mimetično) kot postmodernistično konstrukcijo likov. Palmer dodaja, da je proučevanje likov kot nedejanskih posameznikov najboljši pristop, ker v primerjavi z drugimi omogoča boljše prepoznavanje pomena njihovih mentalnih lastnosti (Palmer, Fictional 38-39).

Margolin je z izpostavljanjem t. i. notranjosti, osebnosti oziroma mentalnih lastnosti literarnih likov anticipiral razvoj kognitivnih pristopov. Med pionirje na tem področju spada tudi Ralf Schneider, ki je v svojem modelu (z upoštevanjem estetike recepcije) izpostavil vlogo empiričnih bralcev. Da bi razumeli literarne like, moramo namreč oblikovati

${ }^{3} \mathrm{~V}$ okviru slovenske literarne vede se je za upoštevanje obeh vidikov, tekstualnega in mimetičnega, zavzela Alojzija Zupan Sosič. Za literarno osebo je zaradi njene dvojne narave uvedla oznako dvoživka, pri čemer je poudarila njeno povezanost $z$ dogajanjem: »Literarna oseba je pripovedna prvina, povezana z dogajanjem. Konstruiramo, doživljamo in razlagamo jo kot dvojno identiteto [...].« (Zupan Sosič 191) 
nekakšno mentalno reprezentacijo o njih, pripisati jim moramo razpoloženja in motivacije, razumeti in razložiti njihova dejanja, razviti pričakovanja o njihovih prihodnjih dejanjih in, seveda, nanje se moramo odzvati čustveno. Vse to se zgodi med kompleksno interakcijo med tem, kar o likih pove besedilo, in tem, kar bralec ve o svetu nasploh, posebej o ljudeh, in še posebej o »ljudeh« v literaturi. (Schneider 608)

Bralci s svojim konstruiranjem mentalnih lastnosti likov so ključni tudi za alternativno teorijo pripovednosti, ki jo je s pomočjo kognitivne lingvistike (tj. z upoštevanjem teorije okvirov in skriptov) razvila Monika Fludernik. Medtem ko je pripovednost običajno definirana s pomočjo zgodb oziroma dogodkov, ${ }^{4}$ jo je avtorica odmevne knjige Towards a 'Natural' Narratology (1996) izrecno umestila na raven bralcev: "Pripovednost nastane v bralnem procesu. (20) Za razvoj kognitivne naratologije je bil pomemben pojem izkustvenosti (experientiality), s katerim je povezala pripovednost: »Pripovednost nastane z izkustvenostjo, tj. s kvazi-mimetično evokacijo 'izkustva iz resničnega življenja'.« (12) Koncept izkustvenosti je kasneje pojasnjevala v različnih člankih in čeprav so se z njim ukvarjali tudi drugi raziskovalci, ostaja kompleksen in odprt za interpretacije. ${ }^{5}$

Čeprav se po eni strani zdi, da izkustvenost nedvomno pripada bralcem, saj jo na podlagi besedila razvijejo (evocirajo) v bralnem procesu, jo je po drugi strani mogoče umestiti na raven besedilnega sveta oziroma povezati z literarnimi liki in pripovedovalci. Nastavek za tako razlago je mogoče prepoznati v konceptu izkuševalca (experiencer), brez katerega bralci ne morejo razviti "vizualizacije izkustvenosti« (245). Vloga izkuševalca je tako pomembna, da "pripovedi brez zgodbe lahko obstajajo, ne morejo pa obstajati pripovedi brez neke vrste človeškega (antropomorfnega) izkuševalca na neki pripovedni ravni.« (13) Kadar je izkustvenost postavljena na raven likov, je izenačena z njihovo zavestjo,

\footnotetext{
${ }^{4}$ Prince je pripovednost izenačil z nizom lastnosti, ki so značilne za pripoved. Naštel je šest njenih konstitutivnih elementov: pripoved je 1) logično konsistentna 2) predstavitev 3) najmanj dveh 4) asinhronih 5) dogodkov, 6) ki ne predpostavljata ali nakazujeta drug drugega (»Narrativehood»19).

${ }^{5}$ Dvajset let po izidu monografije Towards a 'Natural' Narratology so ji na mednarodni konferenci v Amsterdamu posvetili dva dogodka, na katerih so sodelovali Jonathan Culler, Maria Mäkelä, Brian McHale, Dan Shen, Marco Caracciolo, Eva von Contzen, Jonas Grethlein, Karin Kukkonen in Monika Fludernik. Njihove razprave so bile objavljene leta 2018 v reviji Partial Answers. M. Fludernik je v odzivu na predstavljena stališča med drugim zavrnila enačenje izkustvenosti z izkustvom, vznemirljiv pa se ji je zdel predlog Jonasa Grethleina, naj se naratologija v bodoče bolj posveti prav konceptu izkustva (»Response« 341-343).
} 
tj. z njihovim (čustvenim) vrednotenjem dogodkov in fizičnim odzivanjem nanje, lahko pa tudi z njihovim mišljenjem oz. "zavestjo samo po sebi $\varkappa^{6}(30)$. Pripovedi, ki v ospredje postavljajo zavest, ne temeljijo na zgodbah, značilne pa so za modernizem in postmodernizem. Najbolj hermetična besedila (npr. nekatere Beckettove drame), ki jih je zvrstno težko opredeliti, so brez zgodb.

$\mathrm{Na}$ ravni pripovedovalcev je izkustvenost dodatno povezana $\mathrm{z}$ dinamiko med konceptoma pomembnosti zgodbe (tellability) in njenega bistva (point). Za pripovedovalca se izkustvenost zgodbe namreč "ne nahaja zgolj v dogodkih samih, ampak v njihovem emocionalnem pomenu in ponazoritveni naravi« (»Natural« 245). Fludernik je ob proučevanju t. i. naravnih pripovedi ${ }^{7}$ opazila, da protagonist $v$ njih običajno sovpada s pripovedovalcem, ki se spominja dogodka, o katerem se mu zdi vredno pripovedovati: "[Izkustvenost] opisuje tipično lastnost naravnih pripovedi, v katerih presenetljivi dogodki vplivajo na protagonista (običajno sovpada s pripovedovalcem) in so razrešeni $\mathrm{z}$ njegovim/i (njenim/i) odzivom/odzivi - zaporedjem, ki zgodbi zagotovi ilustrativno bistvo [...].« (245) Naravna pripoved je prototip za oblikovanje pripovednosti, zato je mogoče na vse pripovedi razširiti ugotovitev, da je pripovedovalčevo čustveno vrednotenje dogodkov pomemben element izkustvenosti.

V okviru razprave, ki se bo ukvarjala $\mathrm{z}$ literarnimi liki v Blatnikovih kratkih zgodbah, je ključna ugotovitev M. Fludernik, da "pripovednost lahko izhaja iz izkustvenega upodabljanja dinamičnih sekvenc dogodkov [...], lahko pa je sestavljena tudi iz izkustvenega prikaza človeške zavesti (Towards 30). $\mathrm{Z}$ analizo treh izbranih primerov želim pokazati, da je pripovednost Blatnikovih kratkih zgodb v veliki meri ali celo popolnoma odvisna od izkustvenega prikaza zavesti, v manjši meri pa

\footnotetext{
${ }^{6}$ Alana Palmerja je najbolj pritegnil ta vidik izkustvenosti, saj jo je prav on izenačil z mentalnimi stanji in epizodami likov; razumel jo je kot sinonim za subjektivnost, zavest oziroma to, kar sam imenuje fikcijski umi (Fictional 32). Medtem ko je Palmer $\mathrm{v}$ omenjenem delu zavest razumel še na tradicionalen, kartezijanski način, torej tako, da jo je enačil s človekovo notranjostjo, je M. Fludernik z upoštevanjem fizičnih (telesnih) odzivov na dogodke nakazala kasnejši razvoj kognitivne naratologije, ki je sprejela idejo o utelešenem umu, kot so jo razvili Francisco J. Varela, Evan Thompson in Eleanor Rosch. V analizi Blatnikovih kratkih zgodb bom skušala slediti terminologiji Monike Fludernik, torej razlikovati med čustvenimi in fizičnimi (telesnimi) odzivi na dogodke ter zavestjo sámo po sebi (mišljenjem), pri čemer vse troje razumem kot del utelešenega uma.

${ }^{7} \mathrm{M}$. Fludernik z izrazom naravna pripoved označuje "spontano pogovorno pripovedovanje zgodb « (Towards 13) in poudarja, da se pridevnik naravno nanaša izključno na »spontano (re)produkcijo in univerzalnost" (15) tovrstnih pripovedi.
} 
od prikaza dogodkov, pri čemer so slednji pomaknjeni v ozadje. Zavest likov, tj. njihovo čustveno in fizično odzivanje na dogodke ter njihovo mišljenje, je pomembnejša od njihovih dejanj, kar je mogoče pojasniti $\mathrm{z}$ avtorjevim pristajanjem na idejo, da ni več mogoče pisati o aktivnih junakih. To spoznanje tematizira "Zgodba o Rošlinu in Verjanku«, $s$ katero začenjam analizo izbranih kratkih zgodb. Zanimalo me bo, kakšno je v njih razmerje med dogodki in zavestjo likov, z upoštevanjem Palmerjeve teorije pripisovanja pa tudi, kako pripovedovalci, liki in bralci pripisujejo mentalna stanja likom ali sami sebi. ${ }^{8}$

\section{"Zgodba o Rošlinu in Verjanku"}

Kratke zgodbe iz zbornika Rošlin in Verjanko, s katerim so se leta 1987 skupinsko predstavili pisatelji, rojeni okrog leta 1960, se medbesedilno navezujejo na slovensko balado, v kateri je obdelan Orestov motiv. Tretjeosebni, vsevedni pripovedovalec v Blatnikovi kratki zgodbi pripoveduje zgodbo o anonimnem K.-ju. Pripoved se začne s poročilom, kako je K. nekega jutra med ostalo pošto prejel vabilo k sodelovanju v zborniku, pri čemer so citirane ključne besede iz realnega vabila, ki ga je podpisal Vlado Žabot. Vabilo ga sprva ne pritegne, toda ko lista po prejeti reviji, naleti na besede: "Naši avtorji ne vedo več, o čem pisati ..." ("Zgodba" 15) Trditev razume osebno, zato se razjezi. V obliki notranjega monologa je podano njegovo razmišljanje o tem, da zmore pisati o čemer koli in kako bi lahko aktualiziral zgodbo iz balade. Zapiše si osnutek: Rošlin je partijski sekretar, intelektualec; Verjanko pogrunta nekaj novega, je mlad, sposoben in ambiciozen; mati je lahko partija ali pa poosebljena Ideja; "zaplet: Ideja (partija) hoče žrtvovati Verjanka v imenu ideološke (partijske) pravovernosti, se pravi enoznačnosti. / Verjanko se ne da. Izvede kakšno ideološko rošado in nenadoma dobi črno piko Rošlin. Verjanko lahko pride na njegovo mesto - - - (16) K. se razveseli svoje ideje, češ hamletovska scena se tako preobrne v ojdipsko. K. je tudi sicer vse bolj navdušen nad svojo aktualizacijo: partija boleha, žrtvuje otroka, vidi tudi povezavo z dejanskimi političnimi spletkami.

\footnotetext{
${ }^{8}$ Palmer je teorijo pripisovanja predstavil v razpravi »Attribution Theory: Action and Emotion in Dickens and Pynchon«, pri čemer so ga mentalna stanja likov zanimala predvsem z vidika motivacije njihovih dejanj. Podobno je zavest likov obravnavala Lisa Zunshine v knjigi Why We Read Fiction: Theory of Mind and the Novel. Kot je opozoril Marco Caraciollo, je poleg funkcionalističnega pristopa, ki je značilen za navedena avtorja, zavest mogoče obravnavati tudi nefunkcionalistično oziroma tako, da »v središče postavimo subjektivno kvaliteto svoje izkušnje» (»Fictional« 42).
} 
$\mathrm{Na}$ začetku Blatnikove zgodbe spoznamo temeljni problem, $s$ katerim so se soočali mladi slovenski pisatelji v 80. letih, tj. problem, o čem sploh pisati. K. skuša Verjanka izoblikovati v lik, ki se mora za uveljavitev novih idej zoperstaviti partiji in spraviti s poti starejšega tekmeca. Verjanko je torej zamišljen kot aktivni junak, takemu junaku pa so se odrekli že predstavniki starejše generacije, t. i. nove slovenske proze. Študentom primerjalne književnosti je idejo o nemožnosti akcije približal karizmatični profesor Dušan Pirjevec, pri čemer se je navezoval na francoski novi roman oz. Alaina Robbe-Grilleta. Ta je v zbirki študij z naslovom Pour un nouveau roman zavrnil tradicionalne koncepte osebe, zgodovine, angažmaja. Prepričan je bil, da romani ne morejo več govoriti o značajih in posameznikih. Ideja, da je roman pripovedovanje zgodbe, je zastarela. Poskusi, da bi podprli ali predstavili neko idejo, so postali neprimerni. Posameznik v sodobnem svetu nima več vloge in zgodbe o vzponu in propadu posameznika ali družine so bile možne samo v preteklosti.

Dovolj smo govorili o osebi. In kaže, žal, da temu ne bo še kmalu konca. [...] $\mathrm{V}$ tem trenutku gre za mumijo, ki še naprej vlada $\mathrm{z}$ istim dostojanstvom čeprav lažnim - sredi vrednot, ki jih ceni tradicionalna kritika. [...] Nekaj velikih sodobnih del ne ustreza kriterijem te kritike. (31-32)

Robbe-Grillet kot primere takih del našteje Sartrov Gnus, Camusevega Tujca, Celinovo Potovanje na konec noči. Imena oseb niso pomembna (npr. K. v Kafkovem Gradu), prav tako ne gre za študije njihovih značajev.

V tem kontekstu postane jasno, zakaj Blatnik ni napisal zgodbe o aktivnem junaku, ampak zgodbo o težavah, ki jih povzroča pisanje take zgodbe. K. se namreč v nadaljevanju vse bolj muči s pisanjem. Ko v NUK študira zgodovino protireformacije, ga znanec zbode $s$ pripombo, da sam ne bere sodobne literature, ker sodobni pisci nimajo smisla za rep in glavo. "Saj ni res, je hotel krikniti K., prav zdaj je napočil revival zgodbe, oživljeni so žanri, vsi zapovrstjo." (18) S stališča lingvistične teorije o načinih predstavljanja zavesti gre $\mathrm{v}$ tem primeru za poročilo o miselnem dogodku; v okviru kognitivnih pristopov, ki se ukvarjajo z vprašanjem, kako je konstruirana zavest, je treba pozornost usmeriti na spremni stavek: »K. je hotel krikniti.» $\mathrm{Z}$ njim pripovedovalec liku pripiše čustveni odziv na govorno dejanje, bralec pa ga lahko interpretira kot ranjenost, ogorčenost, nemoč itd. K. se je zaradi trditev o sodobnih pisateljih razburil že drugič, kar utrdi bralčevo predstavo, da gre za razdražljiv in nesamozavesten značaj, ki ima težave s predstavo o pomenu sodobnega pisatelja in z lastno podobo. Izkaže se, da znanec tudi sam 
razmišlja, da bi napisal zgodbo o Rošlinu in Verjanku. K. je presenečen, ker naj bi se znanec bolj ukvarjal s teorijo, vendar se ta izmakne $\mathrm{z}$ odgovorom, da sta se literatura in teorija že tako zbližali, da ne veš več, kje se neha ena in začne druga. Zgodba K.-jevega znanca očitno ne bo temeljila na ideji, tudi ne bo zgodba o udejanjanju ideje, ampak bo balado o Rošlinu in Verjanku predelal v nekakšen teoretsko-literarni hibrid. Bralec postopoma spozna, da ta načrt uresničuje Blatnik s svojo kratko zgodbo.

V nadaljevanju "Zgodbe o Rošlinu in Verjanku“ izvemo, kako je $\mathrm{K}$. opustil idejo, da bi svojo zgodbo postavil $\mathrm{v}$ čas protireformacije. Razmišlja, da bi jo prestavil v nedoločeno prihodnost in pokazal, kako bedno se bodo stvari razvile. "Bil je namreč prepričan, da gre z deželo, v kateri živi, strmo navzdol.« (18) Od ideje, da bi Rošlina prikazal kot cinika in odgovornega za bedne razmere, ga odvrne pomislek, da bi Verjanko napovedoval boljšo prihodnost, če bi ubil ali se drugače znebil Rošlina. K.-jeva razmišljanja nakazujejo, kako neodločen je glede pisanja, opozarjajo pa tudi na njegovo zanimanje za družbeno dogajanje; gre za izkustveno prikazovanje zavesti. Sledi medzgodba, v kateri K.-ja obišče sestrična, ki se je $v$ študentskih letih izselila v Kanado. Iz njunega pogovora izvemo še več o življenju v Jugoslaviji v letu 1986 (ko je nastalo realno vabilo $\mathrm{k}$ sodelovanju $\mathrm{v}$ zborniku): uslužbenka $\mathrm{v}$ turistični pisarni je bila neprijazna, letalo je imelo zamudo, en motor ni delal, prva vrsta sedežev je bila razbita, na oddelku za nekadilce so vsi kadili, tudi stevardesa je bila nevljudna. K. brani stevardeso, češ da je slabo plačana, prizna pa, da ni z vsem zadovoljen. Sestrična ga vpraša, zakaj se tudi sam ne izseli, K. pa se izgovori, da je pisatelj, in pretvorjeno citira Wittgensteina: "Meje mojega sveta so meje mojega jezika." (20) K. ve, da je sestrična narobe (»transcendentalno«) razumela njegovo izjavo: »Pišem ... [...] Da preživim, « vendar ji tega ne pove (20). Prizor se konča s sestričninim občudovanjem, pri čemer lahko zaznamo pripovedovalčevo ironijo - K. je namreč deležen občudovanja, čeprav sam ve, da si ga ne zasluži.

Prizoru $s$ sestrično sledi izpust v dogajalnem času. Prišla je jesen, K.-ju pa se zgodba ni hotela zaključiti, zmeraj se je zaustavil tam, kjer bi moralo priti do preobrata, kjer bi moral pobudo prevzeti Verjanko. "Tega K. ni znal napisati. Pravzaprav ni niti vedel, kako naj ta veliki preobrat utemelji.« (21) Pripovedovalec s tem pove, da sodobni pisatelj ne more pisati o aktivnem junaku, ker ne zna utemeljiti akcije. K. se obtožuje, da nima pisateljske domišljije. Razmišlja, da je Verjankova akcija morda možna samo v literaturi (tj. v baladi), v življenju pa ne. Zaradi časovnega pritiska se odloči, da bo opustil prvotno zamisel in 
zgodbo končal drugače. Njegov Verjanko se ukloni volji Ideje, kar stori tako, da javno sprejme kritiko. Izjava »tovariši, sprejemam kritiko« je bila v socialističnem družbenem sistemu znana in vsaj pričakovana, če že ne pogosto uporabljena. Dvojni pomen te izjave se bralcu razkrije šele za nazaj, ko prebere Blatnikovo zgodbo do konca.

Pripoved se nadaljuje s prizorom v kavarni, kjer se K. napije in vsem razlaga o svoji zgodbi. Iz njegovih izjav je razvidno, da Verjanka razume kot metaforo za svojo generacijo, ki ni zmožna akcije. Pravi: »Tako je. Takšni smo. Strahopetci! Cincarji! Postmodernizem, ja! Čas omejenih možnosti, ja! Revščina! Nobenih velikih dejanj. Hamlet! Reve! Nekaj storiti! Nekoga ubiti! Ne morete, kaj? Reve! Reve.» (22) K. še isto noč sanja "strašne" sanje, kot jih označi pripovedovalec. Šele iz opisa teh sanj bralec izve, da ima $\mathrm{K}$. očima. $\mathrm{V}$ sanjah namreč skuša $\mathrm{K}$. prav njega pobiti pred materinimi očmi, vendar mu to nikakor ne uspe. Pozorni bralec na tem mestu (če ne prej) ugotovi, da obstaja podobnost med K.-jem in Verjankom, sledi pa še več namigov. K. zjutraj ugotovi, da je ostal brez sobe, ker je dolžan najemnino. Denar skuša najprej dobiti od urednika Ž. (in sicer za še neobjavljeno zgodbo o Rošlinu in Verjanku), potem pa se odpravi k mami. Na poti k njej razmišlja, da je dobrotljiva mati literarni arhetip, pri čemer navrže naslednji namig: "Življenje in literatura! Kje se neha prvo in začne druga?" (23) Namigov, da je K. zelo podoben Verjanku, $s$ tem ni konec. Mama se je v zadnjih mesecih vnovič poročila, po mnenju K.-ja povsem brez potrebe. Mama se izgovori, da je bolna (kot v baladi!), ne more opravljati popoldanskega dela in mu zato odreče pomoč. K. se ne more odločiti, kaj bi ji odgovoril, in sklene molčati. Tudi ko v sobo vstopi očim, se ne zgodi nič usodnega z njim izmenja nekaj besed in se poslovi. Pripovedovalec tudi na tem mestu ne komentira podobnosti med K.-jem in Verjankom iz K.-jeve zgodbe, s K.-jevim nekonfliktnim vedenjem pa ponovno izpostavi njegovo neodločnost in nemoč za kakršno koli delovanje.

K. v naslednjih dneh razmišlja, da bi moral zgodbo, predvsem njen zaključek, napisati drugače. Toda na osnovi obiska pri materi in dogodkov, ki še sledijo, lahko sklepamo, da je zgodba čisto ustrezna. Še enkrat se namreč potrdi, da obstaja podobnost med K.-jevim življenjem in njegovo zgodbo oziroma da je spravljivi, nedejavni Verjanko metafora za K.-ja. Kaj se torej zgodi K.-ju? Življenje se mu na videz obrne na bolje. Dobi sobo in obeta se mu objava neke zgodbe v literarni reviji. Toda uredniku te revije ni všeč, da je K. sodeloval pri projektu Rošlin in Verjanko. K. obljubi, da bo zgodbo umaknil. Ko to stori, ga znanec A. (za to kratico se lahko skriva Avtor ali pa kar Andrej Blatnik) prosi, naj mu dovoli, da uporabi kos njegove zgodbe v svoji. 
Ko K. pokima, A. reče: »Mislil sem, da ne boš imel nič proti. [...] Ti imaš ideje, tebi se reči dogajajo ... Pisati pa ne znaš. Nič hudega, drugi bodo pisali o tebi. Ti si poklican, da živiš, in ne, da pišeš!« (26) In K. spet samo pokima. Sprejel je torej kritiko in $s$ tem potrdil podobnost z Verjankom iz svoje zgodbe.

Sledi samo še lapidaren epilog, iz katerega izvemo, da je K. svojo zgodbo vrgel v Ljubljanico. Zadnja poved se glasi: »K. opazuje z mosta; zdi se, kakor da misli, da je s tem zgodba o Rošlinu in Verjanku zanj končana." (26) Kako razumeti ta konec? Ali se K. zgolj ponovno odpove kakršni koli akciji? Ali pa je v besedah »zdi se, kakor da misli« skrit še kakšen namig? Če pripovedovalec namiguje, da zgodba o Rošlinu in Verjanku za K.-ja še ni končana, kaj se mu lahko še zgodi? Mogoče to, da bralec ozavesti, da je K. literarni lik v zgodbi, ki jo je napisal A.? Bralec, ki sledi toku teh misli, se zave, da bere literarno delo, fikcija je torej razkrita kot fikcija. Teoretsko poučeni bralec tudi ve, da je Blatnik za strukturo svoje zgodbe uporabil postopek mise en abyme, zgodbo v zgodbi. Blatnikova kratka zgodba tako na ravni zgodbe (kaj se zgodi) kot pripovedi (kako je zgodba povedana) vsebuje postmodernistična sporočila: subjekt ni več zmožen velikih dejanj, med življenjem in literaturo ni meje, resničnosti ni (tudi življenje je fikcija, izmišljija). Ta spoznanja načeloma niso usodna, tragična. Postmodernistični pripovedovalec uživa v igri, $v$ svoji sposobnosti razumevanja in $\mathrm{v}$ izmišljanju novih svetov, zgodb. Njegova glavna lastnost je, da opozarja, da ni naiven. Toda položaj ustvarjalca, ki si za cilj zada razkrivanje svoje nenaivnosti, ni optimističen, saj je njegovo sporočilo zelo omejeno: vse je bilo že povedano, vse je citat, vse je literatura.

Zato ne preseneča, da je Blatnik svojo "Zgodbo o Rošlinu in Verjanku" v knjigi Biografije brezimenih (1989) dopolnil še z enim metafikcijskim obratom. Novi naslov se glasi "Nadaljevanje in konec zgodbe o Rošlinu in Verjanku«. V dodatku se prvoosebni pripovedovalec razkrije kot avtor "Zgodbe o Rošlinu in Verjanku«: "A., Ž.-jev sourednik pri zbirki, sem namreč jaz."(Biografije 32) A. natančno razloži, kako si je zamislil svojo zgodbo in zakaj je potreboval K.-ja in njegovo zgodbo. Ko je zbornik izšel, naj bi kritiki, pa tudi sam, ugotovili, da K.-jeva odločitev, da zgodbo umakne, ni dovolj utemeljena, da se zgodba na tem mestu sesuje. Ko razmišlja o tem, ustvari še en mise en abyme. Kot avtor je v vlogi Rošlina simbolno ubil ne samo K.-ja, tj. Verjankovega pisateljskega očeta, ampak tudi njegovega sina, tj. njegov izdelek, njegovo zgodbo. S tem je vzorec iz K.-jeve zgodbe preselil v življenje. Razmišlja, da je njegova dolžnost, da neha pisati in se docela prepusti resničnosti in živi. To bi pomenilo, da bi ga čakala usoda 
K.-ja, tudi on bi postal lik v zgodbi nekoga drugega. To bi se lahko nadaljevalo v neskončnost. Da bi spiralo pretrgal, pravi, je ena sama možnost: zgodbo bi moral objaviti táko, kot je. Kratka zgodba se konča takole: "Če sedaj, bralec, bereš te vrstice, potem sem zgodbo objavil, potem sem pretrgal spiralo, potem sem (kako klavrno!) 'zmagal'. A tako je položaj še neznosnejši: kaj dobrega lahko prinaša 'Rošlinova' zmaga?» (37) Konec je torej ponovno odprt, bralec lahko sam išče odgovore na zastavljeno vprašanje in ustvarja morebitna nadaljevanja.

Dogajanje v "Zgodbi o Rošlinu in Verjanku« je, kot je razvidno iz povzetka, razmeroma skromno. K.-jeva glavna dejanja so: pisanje zgodbe o nedejavnem junaku, odločitev, da zgodbe ne bo objavil, in njeno uničenje. Pripovedovalec z opozorili na podobnost med K.-jem in likom iz njegove zgodbe bralca napeljuje k ugotovitvi, da je tudi K. fiktiven. Poanta K.-jeve zgodbe je, da ni mogoče pisati o aktivnem junaku. Poanta zgodbe o K.-ju je, da se literatura lahko nanaša samo na literaturo. Razkritje K.-jevega ontološkega statusa je značilen primer postmodernistične konstrukcije likov in ne izključuje pripisovanja zavesti. K.-ju mentalna stanja pripisujeta tretjeosebni vsevedni pripovedovalec in bralec. Predstavljeni so njegovi čustveni odzivi na dogodke (jeza, nemoč), njegov fizični odziv (kadar se s kom pogovarja, pogosto umolkne) in njegovo razmišljanje, ki se vrti okrog pisanja zgodbe, v manjši meri tudi okrog vprašanja, kako priti do denarja za preživetje. Ko bralec konstruira K.-jevo zavest, poleg besedilnih namigov upošteva svoje znanje o (fiktivnih) ljudeh, pri čemer ima pomembno vlogo vednost o vlogi aktivnih junakov v književnosti. K.-jevo pisateljsko nemoč lahko vrednotimo na različne načine, npr. s sočutjem, toda zdi se, da besedilo napeljuje $\mathrm{k}$ ironični distanci in blagemu posmehu. Za pripovednost "Zgodbe o Rošlinu in Verjanku" sta odzivanje na dogodke in predstavitev zavesti pomembnejša od same zgodbe.

\section{"Vlažne stene»}

Minimalistična kratka zgodba »Vlažne stene« iz zbirke Biografije brezimenih (1989) je napisana v obliki poročila o dialogu, ki ga v sedanjem času podaja prvoosebni pripovedovalec in obenem fokalizator. Začetek je neposreden, pripovedovalec brez kakršnega koli uvoda navede svoje besede, namenjene ženskemu liku. Prizor je postavljen v kopalnico, ženska se je ravno nehala tuširati, gola je in mokra, zahteva, naj ji moški poda brisačo. Bralec lahko postopoma rekonstruira predzgodbo: ko se je moški vrnil domov, je v svoji postelji našel drugega moškega; 
upravičeno je domneval, da je imela ženska z njim spolni odnos, odšel je v kopalnico in zdaj zahteva pojasnilo. $\mathrm{V}$ nasprotju $s$ pričakovanim potekom dogodkov, kot ga lahko predvideva bralec na podlagi svojega poznavanja podobnih (fiktivnih ali realnih) scenarijev, se pogovor ne razvije v besedni ali celo fizični obračun moškega z žensko in/ali njenim novim ljubimcem. Nasprotno, zgodba se razplete z njenim zapeljevanjem pripovedovalca.

Za presojo o pripovednosti kratke zgodbe »Vlažne stene« je bistveno, da se je ključni dogodek zgodil še pred njenim začetkom. Dogajanje v sami zgodbi je minimalizirano, zato je konstruiranje pripovednosti skoraj v celoti odvisno od tega, kako se na dogodek iz predzgodbe odzivata oba glavna lika, neimenovani moški in ženska. $\mathrm{O}$ tretjem liku, ki leži $\mathrm{v}$ spalnici in kadi uvoženo cigaro, izvemo zelo malo; edini je poimenovan, pri čemer je njegovo neslovensko ime (Donald), skupaj s podatkom, da je črnec, element, ki prispeva k absurdnosti in komičnosti situacije. Moški ve, da bi moral reagirati odločno in samozavestno, vendar se klavrno končajo vsi njegovi poskusi, da bi v ženski prebudil občutek krivde. Medtem ko govori, neprestano razmišlja o tem, kako ga dojema ona. Zaveda se, da ne izbira pravih besed, in ker upa, da zveni kot "Richard Burton, ki igra Tita," se zdi, da ve tudi to, da v vlogi ogorčenega prevaranega moškega ni prepričljiv (Biografije 108). Njegova čustvena stiska se stopnjuje, vendar je bolj kot z odkritjem prevare povezana z njegovim zavedanjem, da se ne odziva ustrezno. Bralec ve, da se moški boji, da ženska misli, da ni "pravi« moški. Pripovedovalec svojega razpoloženja ne poimenuje, pač pa ga nakaže z opisom čutnih zaznav in telesnega odziva ter s poročanjem o svojih mislih: "Gledam: po ploščicah vijugasti potočki. Kapilare. Čutim: na sencih, na čelu, na vratu utripa. Vem: nekaj narediti. Vem: nekaj reči.« (108) Če se za trenutek zdi, da bo zaradi jeze (ki jo nakazuje utripanje) lahko odreagiral v skladu s svojim (in verjetno bralčevim) pričakovanjem, prevlada občutek nesamozavesti ob golem ženskem telesu: »Vem: potim se. Če to opazi, sem izgubil." (109) Moški ve, da nikakor ne zmore odločnega dejanja, zato mu preostane samo to, da se bolestno ukvarja $\mathrm{z}$ vprašanjem, kakšen je v očeh ženske. Ko se zave, da ga je telo pustilo na cedilu s potenjem, ki izdaja njegovo negotovost, se iz vsaj na videz napadalne drže dokončno premakne $\mathrm{v}$ obrambno.

Medtem ko pripovedovalec samemu sebi pripisuje mentalna stanja, nima neposrednega dostopa do zavesti ženske, pa tudi njegovi poskusi, da bi ugotovil, kaj ona misli ali čuti, niso uspešni. Ker se na njegove poskuse, da bi se začela braniti, ne odziva, ji bralec pripiše mirnost, odločnost in zbranost. Način, kako od moškega zahteva brisačo, naka- 
zuje njeno dominantno vlogo v odnosu, pri čemer prevlado obdrži do konca zgodbe. Medtem ko moški njej nikakor ne more vzbuditi občutka krivde, mu ona uspešno poočita, da je pri večerji ni poslušal. Brala mu je o ameriških raziskavah, po katerih imajo uspešne ženske njenih let na Zahodu stalno razmerje z vsaj dvema moškima. Prav zaradi ameriških raziskav si je omislila drugega moškega. "Ne jemlji tega osebno, reče. Morala sem pač najti še enega, saj razumeš. Proti tebi nimam nič. Vse to je matematika.« (109) Pripovedovalec je do tega razkritja zadržan, poskuša ugovarjati, toda ob pogledu na golo telo ženske je še vedno brez moči. Tolaži ga samo to, da ima izbiro. Zgodba se konča z besedami: "Če govorim, bo trajalo. Če obmolknem, se bo izteklo. Imam izbiro. To je važno: izbira. Torej? Torej.« (111) Konec zgodbe je odprt, mogoče ga je razumeti kot metafikcijski komentar, s katerim pripovedovalec razkrije, da je zgodba, ki jo pripoveduje, odvisna od njega. S tem si pridrži vlogo gospodarja na drugačni, zanj verjetno pomembnejši ravni, kot mu jo je ponudila ženska z besedami: „Naj [Donald] ve, kdo je gospodar.« (110)

\section{»Iz strasti «}

V "Vlažnih stenah" in drugih kratkih zgodbah iz zbirk Biografije brezimenih (1989), Menjave kož (1990), Zakon želje (2000) ter Saj razumeš? (2009) je govorjenje glavni postopek, ki omogoča vpogled v zavest literarnih likov, pri čemer je ta pomembnejša od njihovih dejanj. Kratka zgodba "Iz strasti«, ki je bila objavljena v zbirki Ugrizi (2018), pa je značilen primer dodatne minimalizacije Blatnikovih zgodb. V njih glasni govor pogosto umanjka, zavest likov je še vedno v ospredju, toda predstavljena je s postopki, kot so vsevedni opis, samogovor, notranji monolog in polpremi govor. Modernistična kratka zgodba "Iz strasti« se začne neposredno, tretjeosebni pripovedovalec navede monolog neimenovane osebe: "Danes je pa ni, si reče.« (Ugrizi 80) Sledi skop opis dogajalnega prostora, $s$ katerim je nakazan družbeni položaj oseb, ki tja zahajajo: "Nekak poskus kavarne, dve mizi, ob pumpi v predmestju." Pripovedovalec komentira, da se prisotni smejijo preveč naglas, pogovarjajo se o tistih, ki jih trenutno ni, vsi poznajo vse. Tretjeosebni komentar prehaja $\mathrm{v}$ prvo osebo množine in drugo osebo ednine, pri čemer je izpostavljen pomen pripovedovanja zgodb: imeti zgodbo tu, kjer »smo si enaki«, pomeni, da "končno nekaj res imaš« (80). S prehajanjem v različne slovnične osebe je položaj pripovedovalca zabrisan, saj ni popolnoma jasno, ali je tudi sam eden izmed rednih obiskovalcev lokala ali pa njihove misli v obliki polpremega govora navaja z vsevedne perspektive. 
Uvodu sledi razmišljanje neimenovanega moškega, pri čemer je največkrat uporabljen polpremi govor, nekajkrat tudi premi govor ali pa je misel izrečena prosto, $v$ obliki samogovora. Bralec lahko postopoma razbere, da gre za voznika tovornjaka, ki se vsako jutro ustavi v lokalu, kjer popije kavo, opazuje neznanko in si domišlja, da sta na zmenku. Iz njegovih pomislekov, ali bi spil še eno kavo, izvemo, da ima težave $s$ srcem in da bi moral shujšati. Pripovednost kratke zgodbe temelji na izkustvenem podajanju voznikovih misli in razpoloženja, medtem ko zunanjih dogodkov ni. Moški v vlogi izkuševalca je najprej razočaran, ker ženska to jutro ni prišla. Zdi se mu, da sta se vse zmenila "na daleč, ne da bi kdaj spregovorila" (80). Njegova zamera se s čakanjem spremeni v bojazen, da se ji ni kaj zgodilo. Kupi časopis in se prepriča, da v bližini ni bilo nobene prometne nesreče, potem pa ga obsede misel, da ji je zaradi ljubosumja morda kaj naredil mož. Voznik se je pripravljen maščevati: "Jebenti, če ji je kaj naredil, ga bom stolkel v polpet." (81) Težava je v tem, da ne ve njenega imena in naslova. Še to, da je poročena, ve samo zato, ker nosi prstan. Čeprav ne more storiti ničesar, se počuti bolje, ker ve, da je pripravljen fizično obračunati s potencialnim nasilnežem. V svojih mislih je namreč izpolnil predstavo o "pravem možu « in prepričan je, da bi ob njegovi odločnosti tudi ona, če bi bila še živa, "vedela, kdo je pravi, kdo je res njen" (81). Razmišlja, da bi potem "res verjel, da mora pazit na srce« (81). Spodbujen s tokom svojih misli se odloči, da bo čakal in kljub vsemu spil še eno kavo. V kratkem epilogu, s katerim se konča kratka zgodba »Iz strasti«, je podan komentar, ki ga bralec lahko pripiše bodisi vozniku tovornjaka ali pripovedovalcu: "Veliko reči se zgodi. Vsak dan veliko reči med ljudmi. Najboljše so tiste, ki se zgodijo iz strasti.« (81) Če tako razmišlja tovornjakar, lahko sklepamo, da verjame, kako je zaradi svojih močnih čustev povezan z neznanko. Če komentar pripišemo pripovedovalcu, lahko v njem razberemo ironijo, saj se v zgodbi nič ne zgodi zares, vse, tudi strast, je zgolj stvar domišljije.

\section{Sklep}

Moški liki v treh analiziranih kratkih zgodbah nimajo imen in fizičnih lastnosti. Izhajajo iz različnega družbenega okolja, vse tri pa povezuje dejstvo, da niso aktivni junaki. Njihova dejanja zato niso v ospredju (K. v "Zgodbi o Rošlinu in Verjanku" napiše zgodbo, poskusi jo objaviti in jo na koncu uniči), omejeni so na govorjenje (v»Vlažnih stenah") ali na zelo vsakdanje početje (čakanje, branje časopisa, pitje kave v kratki 
zgodbi »Iz strasti«). Za narativizacijo obravnavanih zgodb je ključno, kako so liki prikazani v vlogi izkuševalcev oziroma kako se čustveno in fizično odzivajo na dogodke ter o čem razmišljajo. Njihova mentalna stanja so kompleksna, obremenjeni so z lastno in družbeno podobo uspešnega pisatelja ali pravega moškega; veliko razmišljajo o tem, kaj bi morali storiti, pa tudi o tem, kako jih dojemajo drugi. Kadar se ukvarjajo z branjem uma drugih likov, praviloma niso uspešni. Mentalna stanja jim pripisujejo pripovedovalci (v "Vlažnih stenah" je pripovedovalec obenem glavni lik) in bralci, za katere je ukvarjanje z zavestjo likov bistvo pripovedovanja oziroma branja. Vedno znova se potrdi, da so moški liki zaradi razkoraka med svojimi hotenji in dejanskim vedenjem nekoliko smešni. Za bralca Blatnikovih kratkih zgodb je zato največja nagrada spoznanje, kako dober je $\mathrm{v}$ branju fiktivnih umov, medtem ko se lahko čustveno distancira od likov.

\section{LITERATURA}

Blatnik, Andrej. Biografije brezimenih. Ljubljana: Aleph, 1989.

Blatnik, Andrej. Ugrizi. Ljubljana: LUD Literatura, 2018.

Blatnik, Andrej. „Zgodba o Rošlinu in Verjanku«. Rošlin in Verjanko. Ur. Vlado Žabot. Ljubljana: Književna mladina Slovenije, 1987.

Caracciolo, Marco. »Fictional Consciousness: A Reader's Manual«. Style 46.1 (2012): $42-65$.

Fludernik, Monika. "Natural Narratology and Cognitive Parameters". Narrative Theory and the Cognitive Sciences. Ur. David Herman. Stanford: CSLI Publications, 2003.

Fludernik, Monika. »Response Essay: Towards a 'Natural' Narratology Twenty Years After «. Partial Answers 16.2 (2018): 329-347.

Fludernik, Monika. Towards a 'Natural' Narratology. London in New York: Routledge, 1996.

Jannidis, Fotis. "Character«. Ur. Peter Hühn idr. The Living Handbook of Narratology. Hamburg: Hamburg University. Splet. 17. januar 2019.

Palmer, Alan. "Attribution Theory: Action and Emotion in Dickens and Pynchon". Contemporary Stylistics. Ur. Marina Lambrou in Peter Stockwell. London: Continuum, 2010.

Palmer, Alan. Fictional Minds. Lincoln; London: University of Nebraska Press, 2004.

Prince, Gerald. A Dictionary of Narratology. Aldershot: Scolar Press, 1988.

Prince, Gerald. „Narrativehood, Narrativeness, Narrativity, Narratability«. Theorizing Narrativity. Ur. José Angel García Landa in John Pier. Berlin: Walter de Gruyter, 2008.

Rimmon-Kennan, Shlomith. Narrative Fiction. London and New York: Routledge, 2002.

Robbe-Grillet, Alain. Pour un nouveau roman. Paris: Minuit. 1963.

Schneider, Ralf. »Toward a Cognitive Theory of Literary Character: The Dynamics of Mental-model Construction."Style 35.4 (2001): 607-640.

Zupan Sosič, Alojzija. Teorija pripovedi. Maribor: Litera, 2017. 


\section{Literary Characters in Andrej Blatnik's Short Stories}

Keywords: cognitive narratology / Fludernik, Monika / Slovenian literature / short story / Blatnik, Andrej / literary characters / narrative structure / experientiality / consciousness

Andrej Blatnik's short stories are based not on the actions of literary characters, but on their consciousness, which is foregrounded. Therefore, appropriate tools for their analysis are concepts that have evolved within the framework of cognitive narratology. In the article, I specifically highlight the notion of experientiality introduced by Monika Fludernik to explain narrativity. Due to its complexity, I seek to explain the concept by pointing to its connection with readers, literary characters, and storytellers. At the level of literary characters, experientiality can be equated with their consciousness, especially when consciousness is understood in relation to the body or as an embodied mind. Blatnik's literary characters respond emotionally and physically to events, reflect on their never-realized plans, and often ponder how others see them. As a rule, they are unsuccessful in reading the minds of other characters, which I show by analyzing three selected short stories: the postmodernist "Story about Rošlin and Verjanko," the minimalist "Wet Walls," and the modernist "Out of Passion."

1.01 Izvirni znanstveni članek / Original scientific article UDK 821.163.6.09-32Blatnik A.

DOI: https://doi.org/10.3986/pkn.v43.i1.09 